ISSN 0258-7122

Bangladesh J. Agril. Res. 35(2) : 297-312, June 2010

\title{
FACTOR DEMAND IN THE HEALTHY RICE SEED USE IN BORO AND T. AMAN: A CASE STUDY OF BANGLADESH
}

\author{
A.S.M. NAZRUL ISLAM ${ }^{1}$ AND S.M. FAKHRUL ISLAM ${ }^{2}$
}

\begin{abstract}
Lack of healthy rice seed is considered as one of the most important constraints to rice production and productivity in Bangladesh. Healthy rice seed production and its use are pre-requisites for accelerate agricultural growth and this can play a leading role in bringing rural prosperity and economic transformation. Therefore, this study analyzes factors demand and elasticity of substitution of healthy rice seed. Data were collected from two different rice growing environments, namely Chuadanga and Gazipur. Primary data from 120 respondents were collected for Boro and T. Aman seasons. Allen Partial Elasticities were estimated for Boro and T.Aman rice for both the study areas. Healthy seed price was highly elastic and the results showed that an increase in the price of healthy seed would decrease its demand. The results showed that if the use of land increased then use of fertilizer, animal + power, seed, irrigation, and human labour would increase. In the T. Aman season, own price elasticities of all the factors had the correct signs. In Gazipur, with one percent increase in price, demand for land, animal power + mechanical power, seed, fertilizer and human labour would fall. The estimates on elasticity of substitution indicated that the best substitutes are land-seed, land-animal power plus mechanical power and land-labour in the Boro season. In the T.Aman season, the best substitutes were found to be land-irrigation in Chuadanga and land-animal power plus mechanical power, land-seed in Gazipur.
\end{abstract}

Keywords : Healthy rice seed, boro, T.aman.

\section{Introduction}

Since independence in 1971, the production of cereal grains in Bangladesh has inceased more than doubled. The production of rice has increased from 17.68 (1995-96) to 27.82 (2007-08) million metric tons and that of wheat decreased from 1.37 to 0.76 million metric tons (Handbook of Agricultural Statistics, 2007, MOA).

The quality rice seed in the country is quite poor with limited market access in Boro and T. Aman season, with only 15\% healthy seeds are supplied by the government through Bangladesh Agriculture Development Corporation (BADC) and non-government agency for the farmers (Fakir et al. 2000). About 85\% own preserved seeds were used by the farmers in Bangladesh for different rice

${ }^{1}$ Principal Scientific Officer, Agricultural Economics Division, Bangladesh Rice Research Institute (BRRI), Gazipur, ${ }^{2}$ Professor, Agricultural Economics Department, Bangladesh Sheikh Mujibur Rahman Agricultural University (BSMRAU), Salna, Gazipur, Bangladesh. 
seasons. Most Bangladeshi farmers preserved their rice seed for the next crop seasons, which is subject to insect and disease infestation. Farmers usually grow rice for consumption or for commercial purpose and save a portion of it as seed. Farmers' such saved seed is never tested for quality.

The importance of quality rice seeds in increasing yield has been widely recognized. With no market access to good quality seed, farmer-to-farmer exchange is generally the major source of seeds in Bangladesh. Continuous saving of seeds from own harvest for seed purpose without proper cleaning would seriously affect seed health leading to lower yields (Mew, 1997). It has been documented that the use of clean and healthy seed of farmers' own harvest can increase yield by 8-10\% in Bangladesh (Diaz et al., 2000). So, it is important that clean and healthy seeds be used as planting materials in order to increase the productivity for eliminating poverty and calorie deficiency of Bangladeshi people. Poor quality seed can reduce germination, seedling growth and crop health, grain quality and yield. Most rice farmers use their own preserved seed for the subsequent crop season, which is subject to insect infestation and disease.

Another important determinant of seed quality is varietal purity. Varietal purity significantly influences the crop yields besides affecting the production practices (Seshu and Dadlani, 1989). It is, therefore, important that farmers become aware of the presence of contaminants in their seeds. Weeds are rival and widespread biological constraints to rice production, causing a conservative estimated loss of $10 \%$ equivalent to 46 million tons per year (Moody, 1991).

Good seed health could be achieved through better management by selecting the seeds from the time of harvest, drying for optimum moisture control for storage, and maintaining scientific storing conditions to protect seeds from seedborne pathogens. For crop and pest management, attention has been paid to cultural practices or curative measures with harmful agrochemicals aimed at protecting the crop health. Seeds carry potential genetic characteristics for successful crop production. It is important that clean and healthy seeds be used as planting materials in order to increase rice yield. Contaminated seeds can often result in poor seedling vigor, and an unhealthy crop (Shenoy et al., 1988).

Farmers usually preserve their own seed following traditional methods. They use bamboo made dole, gunny bag, earthen pot, jar, etc. as storing containers. Farmers with very little knowledge can hardly maintain required moisture level for better seed health. They usually store the seeds using their own experience. They also use the same floor for threshing rice seed, resulting in the possibility of admixture of seeds from different rice varieties. So, it becomes really difficult for rice growers to maintain pure seed. They cannot avoid varietal admixture. Consequently, the viability of those seeds deteriorates in the subsequent season. 
As a result, the farmers are forced to buy clean seed from the open market which is also not dependable.

The specific objective of the present study is as follows.

i) to examine factors demand elasticity and elasticity of substitution of healthy seed for growing Boro and T.Aman rice.

\section{Methodology}

The study was conducted in Chuadanga and Gazipur districts. These two areas were selected purposively for three reasons. First, they represented different rice environments. Chuadanga district was selected as drought prone area and Gazipur was selected as favourable area. In Chuadanga, farmers used shallow tube well for irrigation in cultivating T. Aman rice, while farmers in Gazipur cultivated T. Aman rice in rainfed conditions. In the Boro season, Chuadanga site farmers collecting rice seed from neighbouring country. Farmers' main sources of rice seed were BADC in both the locations. Farmers' also exchange seed with neighbouring farmers, and also purchase from the local market. Four selected villages, namely Amirpur, Hatikata, Maona, and Khittapukurpar,

In the third year socio-economic and biophysical data were gathered using a structured questionnaire designed for this study, Information was generated from two villages in Chuadanga and Gazipur district, through formal interview of 120 farmers and from these two villages 30 participants farmers from each village were employed for experiment in Boro and T. Aman seasons. Other socioeonomic and biophysical data were also gathered with a structured questionnaire.

\section{Analytical technique}

The technical rate of substitution (TRS) measures the slope of an isoquant. The elasticity of substitution measures the curvature of an isoquant. More specifically, the elasticity of substitution measures the percentage change in the factor ratio divided by the percentage change in the TRS, with output being held fixed. If we let $\Delta\left(\mathrm{x}_{2} / \mathrm{x}_{1}\right)$ be the change in the factor ratio and $\Delta$ TRS be the change in the technical rate of substitution, we can express this as

$$
\sigma=\frac{\frac{\Delta\left(x_{2} / x_{1}\right)}{x_{2} / x_{1}}}{\frac{\Delta T R S}{T R S}}
$$

This is a relatively natural measure of curvature: it asks how the ratio of factor inputs changes the slope of the isoquant changes. If a small change in 
slope gives us a large change in the factor input ratio, the isoquant is relatively flat which means that the elasticity of substitution is large. In practice, we think of the percent changes being very small and take the limit of this expression as $\Delta$ goes to zero. Hence, the expression for $\sigma$ becomes

$$
\sigma=\frac{T R S}{x_{2} / x_{1}} \frac{d\left(x_{2} / x_{1}\right)}{d T R S}
$$

It is often convenient to calculate a using the logarithmic derivative. In general, if $y=g(x)$, the elasticity of $y$ with respect to $x$ refers to the percentage change in $y$ induced by a small percentage change in $\mathrm{x}$. That is,

$$
\varepsilon=\frac{\frac{d y}{y}}{\frac{d x}{x}}=\frac{d y}{d x} \frac{x}{y} .
$$

Provided that $\mathrm{x}$ and $\mathrm{y}$ are positive, this derivative can be written as

$$
\varepsilon=\frac{d \operatorname{In} y}{d \operatorname{In} x} .
$$

To prove this, note that by the chain rule

equals sign, we have

$$
\frac{d \operatorname{In} y}{d \operatorname{In} x} \frac{d \operatorname{In} x}{d x}=\frac{d \operatorname{In} y}{d x} .
$$

Carrying out the calculation on the left-hand and the right-hand side of the

$$
\begin{aligned}
& \frac{d \operatorname{In} y}{d \operatorname{In} x} \frac{1}{x}=\frac{1}{y} \frac{d y}{d x} \\
& \frac{d \operatorname{In} y}{d \operatorname{In} x}=\frac{x}{y} \frac{d y}{d x} .
\end{aligned}
$$

Alternatively, we can use total differential to write

So that

$$
\begin{aligned}
& d \operatorname{In} y=\frac{1}{y} d y \\
& d \operatorname{In} x=\frac{1}{x} d x,
\end{aligned}
$$

$$
\varepsilon=\frac{d \operatorname{In} y}{d \operatorname{In} x}=\frac{d y x}{d x y} .
$$


Again, the calculation given first is more rigorous, but the second calculation is more intuitive. Applying this to the elasticity of substitution, we can write

$$
\sigma=\frac{d \operatorname{In}\left(x_{2} / x_{1}\right)}{d \operatorname{In} T R S}
$$

(The absolute value sign in the denominator is to convert the TRS to a positive number so that the logarithm makes sense.)

In the estimation of production models, the standard hypothesis is that the production function belongs to a restricted class which satisfies a priori restrictions of positive monotonicity and quasi-concavity on factor inputs (Nadiri, 1978). The production functions most frequently used are the Cobb-Douglas, the CES, and the Translog, (Christensen, Jorgenson and Lau, 1971). Each of these functions imply different restrictions on the properties of the technology. The Cobb-Douglas function restricts all Allen partial elasticities of substitution to be equal to one. The CES function restricts the above elasticities to be constant and equal for any pair of inputs and for all points in input space. In addition, both the Cobb-Douglas and the CES functions assume strong separability. The Translog function, on the other hand, does not restrict the values of the elasticity of substitution at any point in input space; moreover, it does not assume strong separability.

The estimation of Translog function has become very popular lately for the flexibility that it provides (Bemdt and Christensen, 1973). The usual estimation procedure has been to work with side conditions for profit maximization in competitive product and factor markets. Under this assumption, side conditions for profit maximization imply a system of semi-logarithmic equations-one equation for each input. Each of these equations gives the cost share of an input as a linear function of the logs of each of the inputs. As long as these assumptions are valid, there is no difference between this approach and a direct estimation procedure (Diewert, 1974). However, if the assumptions are not valid, it becomes impossible to know if the parameters that one is estimating are those of a translog function, or a spurious set resulting from misspecification introduced by the use of untested and incorrect assumptions.

The Translog cost function developed (Christensen, Jorgensen and Ian, 1971) does not imply any restrictions on elasticity of substitution. The present study utilizes duality theory for estimating the parameters of the Translog cost function. The Translog cost function that corresponds to a linear homogeneous production function has some parametric constraints. The present study assumes that the farmers' production technology is represented by the following Translog cost function. 
The Translog cost function was particularly used in this context to measure factor demand elasticities and elasticities of substitution. It is written as a logarithmic Taylor series expansion to the second term of a twice differentiable analytic cost function.

In $\mathrm{C}^{*}=\mathrm{f}\left(\right.$ in $\mathrm{Y}$, in $\mathrm{P}_{1}$, in $\mathrm{P}_{\mathrm{n}}$ ), where $\mathrm{C}, \mathrm{Y}$ and $\mathrm{P}_{\mathrm{i}}$ stands for cost, output and input price, respectively. From the Taylor series expansion, it is expressed as follows:

in $\mathrm{C}^{*}=\mathrm{v}_{0}+\mathrm{v}_{\mathrm{y}} \mathrm{inY}+\sum v_{i} \operatorname{In} P_{i}+1 / 2 \sum \sum \gamma_{i j}$ In $\mathrm{P}_{\mathrm{i}}$ In $\mathrm{P}_{\mathrm{j}}+\sum \gamma_{i y}$ In $\mathrm{P}_{\mathrm{i}} \operatorname{In} \mathrm{Y}+\mathrm{U}$

The function is an approximation of an arbitrary analytic function. It is a function form in its own right if the remainder is neglected and if we assume all derivatives and cross derivatives to be constant. This later constraint is imposed if the parameters are estimated in regression equation.

Homogeneity in prices is defined as follows:

$\lambda \mathrm{g}\left(\mathrm{Y}, \mathrm{P}_{1}, \ldots \ldots \ldots \ldots \ldots \mathrm{P}_{\mathrm{n}}\right)=\mathrm{g}\left(\mathrm{Y}, \lambda \mathrm{P}_{1}, \lambda \mathrm{P}_{\mathrm{n}}\right)$. It implies $\sum \mathrm{v}_{\mathrm{i}}=1 ; \sum \gamma_{i j}=0 ; \sum \gamma_{i y}=0$.

Homogenety of degree one in prices does not impose homogeneity of degree one of the production function in inputs. Almost no constraints are imposed on elasticities of substitution or of factor demand, which makes the function more general than other functional forms currently in use.

The function can be estimated directly or in its first derivatives which, by Shepar\&s lemma

$\left(\frac{\delta C^{*}}{\delta P_{i}}=X_{i}\right)$ are factor shares:

$\frac{\delta \operatorname{In} C^{*}}{\delta \operatorname{In} P_{i}}=a_{1}=v_{i}+\sum_{j} \gamma_{i j} \operatorname{In} P_{j}+\gamma_{i y} \operatorname{In~Y} \quad(\mathrm{i}=1 \ldots \ldots \ldots \ldots \ldots \ldots \ldots)$

Both sets of estimation equations are linear in logarithms and have proper exogenous variables on the right hand side if the analysis pertains to firms or an industry.

The $\gamma_{i j}$ parameter has little economic meaning of their own. It will prove that they are related to variable elasticities of substitution and of factor demand as follows;

$$
\begin{array}{ll}
\sigma_{i j}=\frac{1}{a_{i} a_{j}} \gamma_{i j}+1 & \text { for all } \mathrm{j}, \mathrm{j} ; \mathrm{i} \neq \mathrm{j} . \ldots \\
\sigma_{i j}=\frac{1}{a_{i}^{2}}\left(\gamma_{i i}+a_{i}^{2}-\alpha_{i}\right) & \text { for all } \mathrm{i}=\mathrm{j} \ldots \ldots \ldots
\end{array}
$$


Also, factor demand elasticity of inputs can be estimated as;

$\eta_{i j}=\frac{\gamma_{i j}}{\alpha_{i}}+\alpha_{j}$

for all $\mathrm{i} \neq \mathrm{j}$

$\eta_{i j}=\frac{\gamma_{i i}}{\alpha_{i}}+\alpha_{j}-1$

for all $\mathrm{i}=\mathrm{j}$

$\mathrm{C}=\mathrm{fn}\left(\mathrm{P}_{1}, \mathrm{P}_{2}, \mathrm{P}_{3}, \mathrm{P}_{4}, \mathrm{P}_{5}, \mathrm{P}_{6}, \mathrm{Y}\right)$

Where, $\mathrm{C}=$ Total production cost, $\mathrm{P}_{1}=$ Price of land, $\mathrm{P}_{2}=$ Price of animal + Power tiller cost, $\mathrm{P}_{3}=$ Price of seed, $\mathrm{P}_{4}=$ Price of fertilizer, $\mathrm{P}_{5}=$ Price of irrigation, $\mathrm{P}_{6}=$ Price of human labour, $\mathrm{Y}=$ Total output (ton)

The following equation was used for Translog cost model;

$\operatorname{InC}=\frac{1}{2}\left[\gamma_{11}\left(\operatorname{InP}_{1}\right)^{2} \gamma_{22}\left(\operatorname{InP}_{2}\right)^{2}+\gamma_{33}\left(\operatorname{InP}_{3}\right)^{2}+\gamma_{44}\left(\operatorname{InP}_{4}\right)^{2}+\gamma_{55}\left(\operatorname{InP}_{5}\right)^{2}\right.$

$+\gamma_{66}\left(\operatorname{InP}_{6}\right)^{2}+\gamma_{y y}(\mathrm{InY})^{2}$

$+\left\{\gamma_{12}\left(\operatorname{InP}_{1} * \operatorname{InP}_{2}\right)\right\}+\left\{\gamma_{13}\left(\operatorname{InP}_{1} * \operatorname{InP}_{3}\right)\right\}+\left\{\gamma_{14}\left(\operatorname{InP}_{1} * \operatorname{InP}_{4}\right)\right\}+\left\{\gamma_{15}\left(\operatorname{InP}_{1} * \operatorname{InP}_{5}\right)\right\}$

$\left.+\left\{\gamma_{16}\left(\operatorname{InP}_{1} * \operatorname{InP}_{6}\right)\right\}+\gamma_{1 Y}\left(\operatorname{InP}_{1} * \operatorname{InY}\right)+\gamma_{23}\left(\operatorname{InP}_{2} * \operatorname{InP}_{3}\right)\right\}+\left\{\gamma_{22}\left(\operatorname{InP}_{2} * \operatorname{InP}_{4}\right)\right\}+$

$\left.\left.\left.\left.\gamma_{25}\left(\operatorname{InP}_{2} * \operatorname{InP}_{5}\right)\right\}+\gamma_{26}\left(\operatorname{InP}_{2} * \operatorname{InP}_{6}\right)\right\}+\gamma_{2 Y}\left(\operatorname{InP}_{2} * \operatorname{InY}\right)\right\}+\gamma_{34}\left(\operatorname{InP}_{3} * \operatorname{InP}_{4}\right)\right\}$

$\left.\left.\left.+\gamma_{35}\left(\operatorname{InP}_{3} * \operatorname{InP}_{5}\right)\right\}+\gamma_{36}\left(\operatorname{InP}_{3} * \operatorname{InP}_{6}\right)\right\}+\gamma_{3 Y}\left(\operatorname{InP}_{3} * \operatorname{InY}\right)\right\}+\left\{\gamma_{45}\left(\operatorname{InP}_{4} * \operatorname{InP}_{5}\right)\right\}$

$\left.\left.\left.+\gamma_{46}\left(\operatorname{InP}_{4} * \operatorname{InP}_{6}\right)\right\}+\gamma_{4 Y}\left(\operatorname{InP}_{4} * \operatorname{InY}\right)\right\}+\left\{\gamma_{56}\left(\operatorname{InP}_{5} * \operatorname{InP}_{6}\right)\right\}+\gamma_{5 Y}\left(\operatorname{InP}_{5} * \operatorname{InY}\right)\right\}+$

$Y_{6 y}\left(\operatorname{InP}_{6} * \operatorname{InY}\right)$

$\gamma_{6 Y}\left(\operatorname{InP}_{6} * \operatorname{InY}\right)+\mathrm{V}_{1} \operatorname{InP}_{1}+\mathrm{V}_{2} \operatorname{InP}_{2}+\mathrm{V}_{3} \operatorname{InP}_{3}+\mathrm{V}_{4} \operatorname{InP}_{4}+\mathrm{V}_{5} \operatorname{InP}_{5}+\mathrm{V}_{6} \operatorname{InP}_{6}+V_{y i n Y} .$.

Where,

LnC $=$ Total production cost (Tk!ha)

$\mathrm{P}_{1}=$ Price of land (for 4 months) (Tk/ ha)

$\mathrm{P}_{2}=$ Price of animal power + Power tiller cost $(\mathrm{Tk} / \mathrm{ha})$

$\mathrm{P}_{3}=$ Price of seed (Tic/ha)

$\mathrm{P}_{4}=$ Price of fertilizer (Tk/ha)

$\mathrm{P}_{5}=$ Price of irrigation of the planted plot (Tic! ha)

$\mathrm{P}_{6}=$ Price human labour (Tic/ha)

$\mathrm{Y}=$ Total output (torilha)

\section{Specification and measurement of variables}

The specified variables which used to carry out the estimation of the Translog cost function are 
a) Total production cost (Tk/ha) b) Price of land for four months (Tk./ha), c) Price of animal+power (Tk./ha), d) Price of seed (Tk./ha), e) Price of fertilizer (Tk./ha), Price of irrigation (Tk./ha), g) Price of human labour (Tk/ha), h) Total output (t/ha)

a) Total production cost: Total is the summation of human labour, bullock labour, seed cost, fertilizer cost, irrigation cost, land value and other costs considered in the analysis.

b) Cost of land: Land cost was calculated as land rent per hectare for the crop season.

c) Cost of animal power: Bullock power was defined as bullock pair days were calculated by per hectare basis.

d) Cost of seed: Seed cost consists of the prices of both purchased and home supplied seed. Seed cost was calculated by per hectare.

e) Fertilizer cost: Fertilizer cost consists of manure (both purchased and home supplied) and cost of chemical fertilizer which included urea, TSP, MP, DAP as per hectare basis.

f) Irrigation cost: Irrigation cost was calculated by per hectare cost basis. Irrigation was used in the specific plot and converted it as per hectare basis.

g) Human labour cost: Human labour cost was calculated of each operation by per hectare basis.

h) Output: Output consists of T. Aman and Boro rice and the production was calculated on per hectare basis.

\section{Some constraints on the parameters of the translog cost function}

(i) It is assumed that the translog cost equation is twice differentiable, so that the Hessian of this equation is symmetric, i.e., $\gamma_{i}=\gamma_{j}$ Where $\mathrm{i}, \mathrm{j}=$ $\alpha_{1}, \alpha_{2}, \alpha_{3}, \alpha_{4}, \alpha_{5}$, and $\alpha_{6}$

(ii) Since it is a cost function, it has to satisfy the economic constraints of linear homogeneity, i.e. total cost doubles when all factor prices double. This implies:

$\sum \alpha_{i}=1, \sum \gamma_{i j}=0, \sum \gamma_{y i}=0, \sum \gamma_{y i}=0, \sum \mu_{t i}=0$ where $\mathrm{i}, \mathrm{j}=\alpha_{1}, \alpha_{2}, \alpha_{3}, \alpha_{4}, \alpha_{5}$, and $\alpha_{6}$.

(iii) The cost function must be an increasing function of the input prices, i.e.

i.e. $\frac{\partial \operatorname{In} C^{*}}{\partial \operatorname{In} P_{i}}=\alpha_{i}=V_{i}+\sum_{j=1}^{6} \gamma_{i j} \operatorname{In} P_{j}+\gamma_{i y} \operatorname{In} Y \operatorname{InY}(\mathrm{i}=1$ 
Concavity in input prices: This implies that $\delta^{2} \mathrm{C} / \delta \mathrm{P}_{\mathrm{i}} \delta \mathrm{P}_{\mathrm{j}}$ must be negative semi-definite within the range of input prices. This condition can be translated into the condition that the partial elasticities of substitution $\left(\sigma_{i j}\right)$ be negative.

\section{Factor share equations}

The factor share equations were derived through the shepherd duality theorem as;

$\alpha_{1}=\frac{\partial C / \partial P_{1} P_{i}}{\partial c}$

$=\frac{\partial \operatorname{In} C^{*}}{\partial \operatorname{In} P_{i}}$

Where $\alpha_{i}$ denotes the factor share of factor $i$, taking the derivative of the equation the different factor share equation can be expressed as follows:

$$
\begin{aligned}
& \alpha_{1}=V_{1}+\gamma_{11} \operatorname{In} P_{1}+\gamma_{12} \operatorname{In} P_{2}+\gamma_{13} \operatorname{In} P_{3}+\gamma_{14} \operatorname{In} P_{4}+\gamma_{15} \operatorname{In} P_{5}+\gamma_{16} \operatorname{In} P_{6}+\gamma_{17} \operatorname{In} P_{2} \mathrm{Y} \\
& \alpha_{2}=V_{2}+\gamma_{21} \operatorname{In} P_{1}+\gamma_{22} \operatorname{In} P_{2}+\gamma_{23} \operatorname{In} P_{3}+\gamma_{24} \operatorname{In} P_{4}+\gamma_{25} \operatorname{In} P_{5}+\gamma_{26} \operatorname{In} P_{6}+\gamma_{27} \operatorname{InY} \\
& \alpha_{3}=V_{3}+\gamma_{31} \operatorname{In} P_{1}+\gamma_{32} \operatorname{In} P_{2}+\gamma_{33} \operatorname{In} P_{3}+\gamma_{34} \operatorname{In} P_{4}+\gamma_{35} \operatorname{In} P_{5}+\gamma_{36} \operatorname{In} P_{6}+\gamma_{37} \operatorname{InY} \\
& \alpha_{4}=V_{4}+\gamma_{41} \operatorname{In} P_{1}+\gamma_{42} \operatorname{In} P_{2}+\gamma_{43} \operatorname{In} P_{3}+\gamma_{44} \operatorname{In} P_{4}+\gamma_{45} \operatorname{In} P_{5}+\gamma_{46} \operatorname{In} P_{6}+\gamma_{47} \operatorname{InY} \\
& \alpha_{5}=V_{5}+\gamma_{51} \operatorname{In} P_{1}+\gamma_{52} \operatorname{In} P_{2}+\gamma_{53} \operatorname{In} P_{3}+\gamma_{54} \operatorname{In} P_{4}+\gamma_{55} \operatorname{In} P_{5}+\gamma_{56} \operatorname{In} P_{6}+\gamma_{57} \operatorname{InY} \\
& \alpha_{6}=V_{6}+\gamma_{61} \operatorname{In} P_{1}+\gamma_{62} \operatorname{In} P_{2}+\gamma_{63} \operatorname{In} P_{3}+\gamma_{64} \operatorname{In} P_{4}+\gamma_{65} \operatorname{In} P_{5}+\gamma_{66} \operatorname{In} P_{6}+\gamma_{67} \operatorname{InY}
\end{aligned}
$$

The translog cost function has a general form since homotheticity and Hicks neutrality restrictions were not imposed a priori. If the production process is not characterized by these properties, the estimated co-efficient of translog cost function was biased.

Several parameters appeared more than once in the cost share equations and again all of the parameters of the cost share equations appeared in the translog cost function. The equality of these parameters is a necessary condition for the system of the equations to be consistent with cost minimizing behaviour. All the costs of rice production were normalized by the other cost that is why the six cost shares reduced at five cost shares and all the terms with other cost were vanished.

\section{Results and Discussion}

\section{Allen partial elasticities of substitution (APES)}

In the translog cost function Allen's partial elasticities of substitution (APES) can be expressed as a function of the cost share equations. The estimates of the APES were calculated for Boro and Transplanted Aman rice on the OLS estimates of the translog cost function. 


\section{Factor demand elasticity and elasticity of substitution of boro rice}

The selected inputs had significant influence on the cost of modem rice production. The price elasticities for the six rice producing factor demands and the elasticity of substitution for Boro rice are presented in Table 1 and Table 2. Own price elasticities of all factors but one have the correct signs in the Boro season (Table 1). Only animal power plus mechanical power, seed, fertilizer, irrigation and human labour have expected negative signs. However, land has appeared with a positive sign. The positive coefficient of elasticity of demand for land implies that if the price of land increases then its demand also correspondingly increases. This is likely to happen in a land scarce country of Bangladesh because of the fact that high population growth leads to greater demand for land. Under the existing land scarce situation in Bangladesh, it is not the money that matters much but the availability of land. Thus dampening demand for land with its increased prices may not be likely. Own price elasticities of animal power plus mechanical power, fertilizer, irrigation, and labour are negative and inelastic as expected in prior economic theory and seed is highly elastic. Their elasticities show that for 1 percent rise in own prices, the demand for animal power plus mechanical power, seed, fertilizer, irrigation, and human labour would fall by $0.22,2.1,0.27,0.17$, and 0.05 percent, respectively, and the 1 percent increase in the price of healthy seed, its demand would decrease by $2.1 \%$. The high price responsiveness or the demand may have serious implication for its production. Production may go down seriously of the price of the same goes up. The government has to be careful to deal with seed price (Table 1).

Table 1. Estimates of factor demand elasticity for Boro rice production at Chuadanga and Gazipur.

\begin{tabular}{l|c|c|c|c|c|c}
\hline \multicolumn{1}{c|}{ Factors } & Land & $\begin{array}{c}\text { Animal power } \\
\text { plus mechanical } \\
\text { power }\end{array}$ & Seed & Fertilizer & Irrigation & Labour \\
\hline Land & 3.47 & -.30 & -.39 & -.72 & -1.25 & -.73 \\
Animal power plus & -.22 & -.09 & .38 & .17 & .11 \\
mechanical power & & -2.1 & .56 & .51 & .02 \\
Seed & & & -.27 & .28 & .09 \\
Fertilizer & & & & -.17 & .12 \\
Irrigation & & & & & -.05 \\
Labour & & & & &
\end{tabular}

Source: Field survey

A considerably different view of the substitability among factors in Boro rice production is revealed by Allen elasticities of substitution as shown in Table 2 
and cross price elasticities presented in Table 1. Allen elasticities of substitution and cross elasticities of demand were assumed positive for substitute inputs and negative for complements. These relationships are easier to evaluate by looking at the coefficients of elasticities.

Table 2. Estimates of elasticity of substitution of factor used in Boro rice production at Chuadanga and Gazipur.

\begin{tabular}{l|l|l|l|l|l|l}
\hline \multicolumn{1}{c|}{ Factors } & Land & $\begin{array}{c}\text { Animal power } \\
\text { plus mechanical } \\
\text { power }\end{array}$ & Seed & Fertilizer & Irrigation & Labour \\
\hline Land & 59.83 & .96 & 1.02 & 0.48 & 0.42 & 0.92 \\
$\begin{array}{l}\text { Animal power plus } \\
\text { mechanical power }\end{array}$ & -0.02 & 1.00 & 0.97 & 1.03 & 1.00 \\
Seed & & 28.43 & 1.05 & 1.05 & 0.99 \\
Fertilizer & & & -0.60 & 0.81 & 0.98 \\
Irrigation & & & & -0.46 & 1.06 \\
Labour & & & & & -0.05 \\
\hline
\end{tabular}

Source: Field survey

The coefficients of cross price elasticities show that complementary relationships exist between land- animal power plus mechanical power pair, land-seed pair, land-fertilizer pair, land- irrigation pair and land-labour pair. It implies that if the use of land would increase then the use of fertilizer, animal power plus mechanical power, seed, irrigation and labour correspondingly would increase. In modern agriculture production process seed, fertilizer, irrigation is important for any modern agricultural technology. In Boro rice season, irrigation is important because Boro rice crop is irrigation based and farmers would save crops from drought by applying irrigation, farmers also would use irrigation after applying fertilizer for efficient use of fertilizer. However seed and fertilizer are also important for modern varieties of rice. Similarly, if the use of seed increases, then the use of labour and animal power plus mechanical power would also be increased because animal power plus mechanical power would lead to rise in the use of seeds, animal power plus mechanical power and labour use is complementary to the use of seed. If the use of seed increases, then the use of labour would increase and if the use of fertilizer increase then the use of irrigation would increase. These types of relationships characterize the requirement of intensive use of such inputs in modern seed technology (Table 1). The best substitutes are land-seed (1.02), land- animal power plus mechanical power (0.96) and land-labour (0.92). The degree of substitution appears to be stronger for these inputs. It implies that due to substitutability between land and 
labour, the land scarce farmers could employ more labour intensively in the Boro rice season. Similarly, the farmers could substitute animal power plus mechanical power for human labour because of farm power scarcity. This type of substitution would also increase employment of farm labour in the country which is desirable in a densely populated rcountry. There exists large literature which has explored the inverse relationship between farm size and productivity (Ali, 1995; Bhalla 1979 and the references cited therein) and found that one of the important reasons for this is the relatively higher labour use per hectare on the smaller farms. Since the implicit labour costs work out to be lower in small farms as their opportunity cost of labour (i.e. returns from the next best alternative) is lower, such farms tend to use more labour per hectare then the larger farms (Table 2).

\section{Factor demand elasticity and elasticity of substitution for T. Aman rice}

Own price elasticities of all the factors in the T. Aman rice season of both the districts have the correct signs (Table 3). Own price elasticities of land, animal power plus mechanical power, seed, fertilizer, irrigation, and labour are negative and inelastic. Their elasticities show that 1 percent rise in own prices, the demand of all factor of T. Aman would fall by $0.25,0.28,0.29,0.26,0.29$, and 0.24 percent, respectively. Similarly in T. Aman season at Gazipur, 1 percent increase in prices of land, animal power plus mechanical power, seed, fertilizer, and human labour would fall by $0.26,0.30,0.28,0.27$, and 0.32 percent, respectively, (Table 4).

The co-efficient of elasticities showed that complementary relationship exist between land- animal power plus mechanical power pair, animal plus power- seed pair, seed-fertilizer pair, fertilizer- irrigation pair and irrigationlabour pair in T. Aman season at Chuadanga. Similarly land-animal power plus mechanical power pair, animal power plus mechanical power-seed pair, seedfertilizer pair and fertilizer-labour pair in T. Aman season at Gazipur. This relationship implies that if use of land increases, the use of animal power plus mechanical power at Chuadanga and Gazipur correspondingly would increase. Similarly, the increase in the use of animal power plus mechanical power would lead to rise in the use of seeds. If the use of seed would increase, then the use of labour increase. If the use of fertilizer increases, the use of irrigation would increase at Chuadanga. Irrigation was not used in the T. Aman season at Gazipur. As a drought prone area, the Chuadanga farmers used irrigation after applying fertilizer in their land. These types of relationships characterize the requirement of intensive use of such inputs in the T. Aman rice production technology (Table 3 and 4). 
Table 3. Estimates of factor demand elasticity for T. Aman rice production at Chuadanga,

\begin{tabular}{l|l|l|l|l|l|l}
\hline \multicolumn{1}{c|}{ Factors } & Land & $\begin{array}{c}\text { Animal power } \\
\text { plus mechanical } \\
\text { power }\end{array}$ & Seed & Fertilizer & Irrigation & Labour \\
\hline Land & -0.25 & 0.54 & 0.51 & 0.57 & 0.52 & 0.60 \\
Animalpowerplus & & -0.28 & 0.51 & 0.57 & 0.52 & 0.61 \\
mechanical power & & & -0.29 & 0.57 & 0.51 & 0.60 \\
Seed & & & & -0.26 & 0.51 & 0.61 \\
Fertilizer & & & & -0.29 & 0.61 \\
Irrigation & & & & & -0.24 \\
Labour
\end{tabular}

Source: Field survey

Table 4. Estimates of factor demand elasticity for T. Aman rice production at Gazipur.

\begin{tabular}{l|l|l|c|c|c}
\hline \multicolumn{1}{c|}{ Factors } & Land & $\begin{array}{c}\text { Animal power plus } \\
\text { mechanical power }\end{array}$ & Seed & Fertilizer & Labour \\
\hline Land & -0.26 & 0.50 & 0.53 & 0.56 & 0.49 \\
$\begin{array}{l}\text { Animal power plus } \\
\text { mechanical power }\end{array}$ & -0.30 & 0.54 & 0.56 & 0.49 \\
Seed & & -0.28 & 0.56 & 0.49 \\
Fertilizer & & & -0.27 & 0.49 \\
Labour & & & & -0.32 \\
\hline
\end{tabular}

Source: Field survey

The existence of complementary relationships in $\mathrm{T}$. Aman season are between land- animal power plus mechanical power pair, land-seed pair, land-fertilizer pair, land-irrigation pair and landhuman labour pair at Chuadanga and landanimal power plus mechanical power pair, land-seed pair, land-fertilizer pair, land-human labour pair at Gazipur. It implies that if the use of animal power plus mechanical power, seed, fertilizer, irrigation and labour increases then the use of land would increase in Chuadanga. Similarly the use of animal power plus mechanical power, seed, fertilizer, and labour increase, then land would increase at Gazipur. These type of relationships characterizes the requirement of intensive use of modern technology inputs in rice production (Table 3 and 4). 
Table 5. Estimates of elasticity of substitution of factor used in T. Aman rice production at Chuadanga.

\begin{tabular}{l|l|l|l|l|l|l}
\hline \multicolumn{1}{c|}{ Factors } & Land & $\begin{array}{c}\text { Animal power } \\
\text { plus mechanical } \\
\text { power }\end{array}$ & Seed & Fertilizer & Irrigation & Labour \\
\hline $\begin{array}{l}\text { Land } \\
\text { Animal power plus }\end{array}$ & -0.40 & 0.98 & 0.99 & 0.96 & 1.00 & 0.93 \\
mechanical power & & 1.00 & 0.99 & 1.00 & 0.97 \\
Seed & & -0.57 & 0.99 & 1.00 & 0.97 \\
Fertilizer & & & -0.44 & 1.00 & 0.97 \\
Irrigation & & & & -0.56 & 0.98 \\
Labour & & & & & -0.37 \\
\hline
\end{tabular}

Source: Field survey

The substituting effect at Chuandanga and Gazipur were explained in Table 5 and Table 6. The elasticities of substitution are between land- animal power plus mechanical power pair, land-seed pair, land-fertilizer pair and land-labour pair at Chuadanga. The best substitutes are land-irrigation (1.00) at Chuadanga and land-animal power plus mechanical power (1.00) and land-seed (1.00) at Gazipur. The degree of substitution appears to be more stronger for these inputs. It implies that due to substitutability between land and irrigation in Chuadanga farmers would use rain water as their substitute of irrigation water in the $\mathrm{T}$. Aman season. Similarly at Gazipur, land-animal plus power, land-seed is the best substitute. The farmers could substitute animal power plus mechanical power for human labour because of farm power scarcity. These type of substitution would also increase employment of farm labour in the country which is desirable in a densely populated country. On the other hand, seed has substitute relationship i.e. if the use of land would increase then the per hectare use of seed would increase. This implies that the producers would like to use healthy seed and they also use own preserve seeds as substitute of healthy seed.

Table 6 Estimates of elasticity of substitution of factor used in T. Aman rice production at Gazipur.

\begin{tabular}{l|l|l|c|c|c}
\hline \multicolumn{1}{c|}{ Factors } & Land & $\begin{array}{c}\text { Animal power plus } \\
\text { mechanical power }\end{array}$ & Seed & Fertilizer & Labour \\
\hline Land & -0.40 & 1.00 & 1.00 & 0.99 & 0.98 \\
$\begin{array}{l}\text { Animal power plus } \\
\text { mechanical power }\end{array}$ & -0.60 & 1.00 & 0.99 & 0.98 \\
Seed & & -0.52 & 0.99 & 0.98 \\
Fertilizer & & & -0.47 & 0.98 \\
Labour & & & & -0.61 \\
\hline
\end{tabular}

Source: Field survey 
Also substitute relationship found with land-fertilizer and land-labour at Chuadanga and Gazipur (Table 5 and 6).

\section{Conclusions}

Factor demand elasticity and elasticity of substitution were estimated for Boro and T. Aman seasons by OLS estimates of the translog cost function. HicksAllen elasticities of substitution and cross elasticities of factor demand were assumed positive for substitute inputs and negative for complements. These relationships were evaluated by looking at the coefficients of elasticities. In the Boro and T. Aman seasons, all the coefficients of own price elasticities of all factors, except one, have correct sign. In Boro season, animal power plus mechanical power, seed, fertilizer, irrigation and human labour have expected negative signs. Their elasticities show that for 1 percent increase in own price, the demand for these factors would fall. Healthy seed is found to be highly elastic and if the price of healthy seed were would increase by 1 percent, demand would decrease by $2.1 \%$.

On the other hand, in T. Aman season, own price elasticities were found to have the correct sign. Own price elasticities of land, animal power p[lus mechanical power, seed, fertilizer, irrigation, and labour are negative and inelastic. Their elasticities imply that 1 percent increase in own prices, the demand of all factors of T. Aman would fall. Although T. Aman is a rainfed crop, sometimes supplementary irrigation is needed because the farmers would not take the risk for no rain. In the Boro season, land-seed, land-animal power plus mechanical power, and land-labour have substitution effect. This type of substitute selection would also increase employment of farm labour in the country.

Complementary relationship existed in land-animal power plus mechanical power, animal power+mechanical power-seed, seed-fertilizer, fertilizerirrigation, irrigation-labour at Chuadanga in the T. Aman season. Complementary relationships were also found in land-animal power plus mechanical power, animal power + mechanical power-seed, seed-fertilizer and fertilizer-labour at Gazipur.

The best substitution effects were found in land-animal power plus mechanical power, land- seed and land-labour pair in the Boro season. In the T. Aman season the best substitutes were found for land- animal power plus mechanical power, land-seed pair, land-fertilizer pair, land-irrigation pair and land-labour pair.

Finally, the factor demand elasticity and elasticity of substitution were estimated. Results indicated that if the input price of rice production increases, the demand for inputs would fall. Seed is highly elastic. If the price of healthy seed increases, the demand for healthy seed would decrease. 


\section{References}

Ali M. 1995. "Institutional and Socioeconomic Constraints on the Second-Generation Green Revolution: A Case study of Basmati Rice Production In Pakistan's Punjab:. Economic Development and Cultural Change, Vol. 45 No. pp. 853-861.

Berndt. E. R. and L. R Christensen. 1973. The Translog Function and the Substitution of equipment, structures, and labour in U. S. manufacturing, 1929-68. Journal of Econometrics. Vol. 2: 8 1-113.

Bhalla. S. 1979. "Farm Size, Productivity and Technical Change in Indian Agriculture” in: R.A. Berry and W. Cline (Eds), Agrarian Structure and Productivity in Developing Countries, Baltimore: Johns Hopkins University Press.

Bangladesh Bureau of Statistics. 1995-96 and 2007-08. Statistical Year Book of Bangladesh, Statistics Division, Ministry of Planning, Government of the People's Republic of Bangladesh, Dhaka, Bangladesh.

Christensen. L. R, D. W. Jorgenson, and L. J. Lau. 1971. Cayugate Daulity and the transcendental logarithmic production function. Econometrica. 39 (4): 255-256.

Christensen. L. R, D. W. Jorgenson, and L. J. Lau. 1971. Cayugate Daulity and the transcendental logarithmic production function. Econometrica 39 (4): 255-256.

Diaz. C. M. Hossain, S. Merca and T. Mew. 2000. The experiment results showed that plot planted with IRRI seeds had $7 \%$ higher yield than the plot planted with farmer kept seeds in the site where the yield level is already high.

Diewert. W. E. 1974. Applications of drality theory, in M. Intriligator and D. Kendrick, ets., Frontiers of quantitative economics, Vol. II (North-Holland, Austerdam).

Fakir. G. A, Ismail Hossain and M. U. Ahmed. 2000. Quality of farmer's saved rice seed in Bogra, Rajshahi and Rangpur sties of Bangladesh. Paper presented in the "Review and Planning Meeting on Rice Seed health Improvement for Increasing Yield”, held at BIDS, Dhaka, during November 25-26, 2000.

Handbook of Agricultural Statistics. 2007. Published by Market Monitoring and information System (MMIS), Ministry of Agriculture.

Mew. T.W. 1997. Seed Health Testing: Progress Towards 21st Century, In: Hutchins and Ruces (eds.), Development in Rice Seed Health Testing Policy, 129-138.

Moody. K. 1991. Weed management in rice. In: handbook of Pest Management in Agriculture (ed. D. Piment el). pp. 301-328, CRC Press, Boca Raton, Florida, USA.

Nadiri. M.I. 1978. Producers theory, in: K.J. Arrow and M.D. Intriligator, eds., handbook of mathematical economics (North-Holland, Amsterdam).

Seshu. D. V. and Malavika Dadlani. 1989. Role of women in seed management with special reference to rice. International rice Testing Progrm (IRTP) Technical Bulleting No. 5. International Rice Research Institute, P.O. Box 933, Manila, Philippines.

Shenoy Sandhya N, T. R. Paris and B. Duff. 1988. Farm level harvest and post-harvest seed management practices of farm women in an irrigated rice system: a case study. Paper presented at "Women in rice farming system network orientation and planning workshop, held at the International Rice Research Institute, Los Banos, Laguna, Philippines, May 2- Il, 1986. 